\title{
Kharkiv's Soulful Places: An Artistic Research
}

\author{
Dmytro Zaiets' \\ Kharkiv School of Architecture
}

\begin{abstract}
What makes certain places in a city fascinating, even magical? This is not about the so-called "nice city" areas, be it views of historical districts or monuments or city parks-places that are by default associated with pleasant ambiance or recreation. This essay is about places that create an immediate impression and that can become intimate, eliciting an emotional response or addressing our hidden needs. It describes research results achieved by sociology students of the Kharkiv School of Architecture in the 2017-18 academic year. The research was dedicated to urban places with a "soul," with all of the possible shades and differences this social construct implies. The purpose of this research was to find a way to recreate the charm of places, to recreate their atmosphere and their aura in other contexts. Overall, this essay emphasizes the importance of authentic places and stresses the need to study and preserve them as a basis for the urban life of contemporary Kharkiv.
\end{abstract}

Keywords: soulful place, authenticity, artistic research, domestication, Kharkiv.

\section{INTRODUCTION: SPECIAL PLACES}

$S^{i}$ ince the events of Ukraine's 2013-14 Revolution of Dignity, Kharkiv has been experiencing a renaissance of gastronomic culture. The turning point in the development of catering establishments was the opening of a new format-the gastropub. The distinguishing features of gastropub establishments (such as "Bufet"1) are good cuisine, pleasing aesthetics, and affordable prices. New cafés and bars serve craft beer and customized burgers with a taste of Ukrainian "freedom": for example, "khrenovukha" (an infusion of vodka and horseradish) or "salo" (fatback). The rise and evolution of gastronomic culture is a product of new socio-political developmentsfor example, the migration of Donetsk businesses after the start of the war in the Donbas. But despite ongoing hardships in Ukrainian society caused by the Donbas war, eateries have become popular among Ukrainian citizensas shown by an overall post-Maidan resurgence of interest in Ukrainian culture and local products. Visiting new bars and cafés has become a new trend, especially among young people. A decade ago, the Churchill Bar, the Agata Art Café, or the "Zhyvot" (Belly) Nightclub were likely to be marginal;

1 "Bufet" (Buffet) is a fast food cafe chain: http://bufet.ua. Accessed 14 Nov. 2019. 
today, visiting bars is a sign of normal urban life for a very wide range of citizens. These changes in the habits of Kharkivites are noticeable against the background of the deteriorating economic situation and stagnant reforms in Ukraine.

Severe economic conditions and intense competition lead restaurant owners to constantly adjust their cuisine and to look for the right "atmosphere" for their establishments. Unfortunately, many places that are created with great effort do not work the way they should, for consumers do not believe in them. Yet there are other places in the city that have been unknown to the general public but have lately become popular. Why is that?

Christian Norberg-Schulz, a Norwegian architect, describes a public places using the categories of "space" and "character," where space comprises the three-dimensional elements of a given place and character is the atmosphere within the place (3). The so-called "cult places" of a city are distinguished from others by a special aura, which is often described as "soul." Visually, these places may look like many others, but places with a soul-I will refer to them as "soulful places" in the course of this essay-offer something that one misses in a city-friendliness and involvement, or a chance to feel kinship with a total stranger. The world and ambience that such places offer their customers make customers believe in what they normally would not.

\section{SOUL SEARCHING: BACKGROUND AND METHODOLOGY}

During the 2017-18 academic year I offered an introductory course in urban sociology through the curriculum of the college preparation program of the Kharkiv School of Architecture. Structurally, the course was a symbiosis of sociological and applied fine arts methodologies within the urban studies domain. The course's main topic was the idea of an urban place as an object of admiration. ${ }^{2}$ Students were offered a predesigned workshop at the beginning of the course, aimed at helping them to analyze city space in order to reveal hidden structures that help facilitate human interaction (that is, so people feel involved), for human involvement is an important aspect of architectural workflow. Students ${ }^{3}$ built their research methodology based on the work of Aleksandra Abdrekhimova, who has explored the

\footnotetext{
2 Students presented their final projects at the sociological exhibition "Sostoianie dushi" (Ukr. "Stan dushi") ("State of Soul," see the plan in Appendix 1). Students used the techniques of collage, comics, board games, and installation formats in their presentations.

3 Twenty-eight students were enrolled in the course, ranging from high school students to adults 28 to 38 years old.
} 
ethnography of bar culture in Saint Petersburg (115). But my students focused on a broader range of urban places, beyond just bars and cafés. The first condition for their selection of places was to avoid homogeneity. The second condition was to go outside the boundaries of the historical centre, which already has a strong symbolic connotation and serves as a marker of the city's identity. Thus, in addition to Kharkiv's vibrant downtown the course took students to the 6th Microdistrict and a neighbourhood called Zhukovskyi Town (aka "Zhuky"). While conducting their research, students applied the methods of observation, interviewing, and sketching (quick drawing). ${ }^{4}$

The research question that students addressed was simple: What makes a place soulful? This question can be answered in a predictable fashion, e.g., the history of the place, as the Ukrainian sociologists Liubov ApostolovaSossa and Alirza Mamedov propose. Following this logic, Kharkiv's soul is concentrated in the historical downtown. In expanding the parameters of the study beyond the old city, however, students relied on Sharon Zukin's concept of "authentic places." For Zukin, the concept of "authenticity" captures not only the past but also something unique and original in the contemporary urban landscape (30). Zukin attributes authenticity to both appearance and a sense of place, as well as the social connectedness and opportunities that the place creates (219). So, my students took a wider perspective and focused on the three parameters of "aesthetic experience," "community" (visitors and hosts), and "particular etiquette" (norms, sanctions, traditions) that a given place demands from its visitors.

The research was accomplished in five phases:

1. A search was made for soulful places with a strong ambiance, capable of causing a vivid emotional response. Students searched for such places based on reviews they found on the Internet or through their own experience of visiting known places in their communities.

2. Autoethnographic descriptions of the soulful places were compiled (i.e., students focused first on understanding and describing their own feelings evoked by the place, and only then interviewed visitors and staff).

\footnotetext{
${ }^{4}$ Our list of places explored included (1) the stairway in Family Dormitory No. 5; (2) "Some Like It Hot" Gastrobar; (3) Bourbon Coffee House; (4) " $\epsilon$ " Bookstore (3 Sums'ka Str.); (5) "Oblomov" anticafé; (6) Lva Tolstogo subway station shopping mall (Kyiv); (7) the slope behind the dorms of the Kharkiv Aviation Institute (KhAI); (8) the courtyard behind the "Salamander Building" (17 Sums'ka Str.); (9) "Starik Khem" Bar; (10) the outdoor chess club at Derzhprom subway station (Kharkiv); (11) the "Titanic" family dormitory (Kharkiv Tractor Plant district); and (12) the gas station near the Boiko school. More information about these places is listed in Appendix 2.
} 
3. Students made observations and sketches of the places they analyzed in order to answer the following questions: Who are the visitors? In what way do they use the space? Why do they consider it special, their own? Based on sketches and observations, the students designed questions for interviewing the visitors.

4. The visitors to and hosts of the selected places were interviewed to determine what they thought about the value of the place, and what characteristics made the place unique.

5. The above information was used to identify and recommend places that radiate energy and enchant their customers.

\section{Community of Soul}

Students picked two types of places: (1) places created for gastronomic pleasures (cafés, bars) and (2) places designed for transit, whose functionality was not intended for meetings and communication: e.g., stairways, house yards, gas stations.

Food industry places (such as a coffee shop or a bar) are designed for all and serve a commercial purpose. The aura of such places is more public and less intimate in terms of communication among its visitors. In contrast, places reserved for a specific audience are created for communication in a narrow circle; thus, they are more exclusive, despite the fact that they often perform a transit function. A transit place is assessed by the extent of its appropriate use and the way particular groups identify themselves with the place. In places of such type, "soulfulness" is achieved through group identity, and such places are often found underground. They are not for everyone, and they have a strong character: they are perceived by visitors as honest, truthful, and unique-"specially for us."

Seeking out and analyzing the soulfulness of a place reveals one of the important concepts of urban sociology-“domestication"-a twofold connection between a person and a place. Relying on the poetic image theories of Gaston Bachelard, students noticed that the search for soulful places is best described by the metaphor "looking for a home." When students would go in search of places with a soul, almost all of them found themselves in enclosed spaces: cafés, bars, dormitories. Their perception brought to life the concept of safety; that is why what they obtained was a series of rooms, corners, spiral staircases, basements, and attics. All objects were gathered under one roof-in an imaginary house. It is in places full of atmosphere that people can find such metaphorical shelters that allows them to hide from the outer world, as if they were back in their childhood where they felt safe. People's memories are concentrated around such places. Beyond decorations and gastronomic delights, students notice not 
the places per se (café or bar), but rather images of the homes they lost or wished they could go back to. The images are created in the process of perception. This process is driven by a variety of circumstances-intentions and wishes, no matter whether visitors recognize them or not. Bachelard's reflections on the problem of looking for a home helped the students to recognize a huge difference between safety in the home and in the outside world. This world may be domesticated to some extent, but it will never be like the real home is.

Research cases were identified in the suburbs as well as in the city centre. The first example is a slope next to the dorms of the Kharkiv Aviation Institute (KhAI). It is located behind a large nine-storey building housing KhAI dormitories 10, 11, and 12. This dormitory block-aka "Kytaika" (after the Great Wall of China) - is located on the outskirts of the city. Kateryna Cherednyk, who studied this place, points out the feeling of safety and coziness one experiences on the slope, which is located in a forest grove. Playgrounds with big logs there and fire pits are a perfect spot for afternoon gatherings with a guitar around a fire. The slope, like any soulful place, creates its own stories, its own little epic tale. To "gather at the slope" means to contribute to the creation of the folklore of this place, to become a hero of the KhAI legend at least for one evening, and then to tell about it at an alumni reunion meeting.

Using the example of this slope, one can talk about the dichotomy of the internal (to hide in a corner) and the external (to have a party, to celebrate) space. This dichotomy can also be found in the backyard of the Salamander building at 17 Sums'ka Street. Ievhen Frants and Oleh Kolesnyk describe as follows the feelings they had while researching that place:

Despite the crazy life rhythm, the courtyard on Sums'ka Street represents an island of tranquility, where one can have a break, rest, and decide what to do next. Or one can just sit there, observe, and feel the city rhythm. The courtyard structure inspires a feeling of safety and comfort . . . . Salamander's cour d'honneur stands for a saving oasis in the heart of an overcrowded street, ready to welcome tired citizens. ${ }^{5}$

The feeling of coziness peculiar to the Salamander building is found in similar shelters and secret places throughout the city, some of which are not designed for housing. The following two locations from the students' research-an apartment stairwell and a gas station-may serve as examples of such places. The entrance/stairwell in family dormitory building No. 5 at 19 Derev"ianko Street helps teens to create new social connections and

\footnotetext{
${ }^{5}$ All translations in this study are my own.
} 
friendships, and even serves a matchmaking functions. Mariia Kolomyitseva observes the following:

The place is dirty, damp, and dark - that is the kind of challenge teenagers meet head-on. This space gives them a feeling of freedom and independence. A chance to hide from prying eyes allows them to do what is forbidden at home: drink, smoke, use foul language, kiss-do whatever they like. Teens get together in groups (forming their own peculiar cliques); each group has its own territory.

Viktor Rakov made similar observations when studying a gas station next to the Boiko school (7 Osvitians'ka Street). This turns into a gathering place for students' parents. Every morning, parents meet there for 20 minutes or so for coffee. This place demonstrates a simple human need to take a break and communicate with people they relate to. In the course of this communication, a group identity takes shape. The gas station's soulful nature is found in the affinity it creates for these parents. Rakov describes it as follows:

A parent gives his child a ride to school. After, he sees the mom or dad of his child's classmate; they start a conversation about how nice the geography teacher is or that it's time for their children to start swimming lessons. They realize they have much in common to discuss and decide to continue while having coffee. They go to the gas station, get a cup of coffee, and discuss, among other things, when and where to get their children braces.

A characteristic feature of communication in such a place is its territoriality. The interlocutor is important only within the boundaries of the venue. A conversation or discussion outside the site is, in fact, not expected, nor is it intended. It turns out that the social connection exists only here and now. Thus, we have an example of a lococentric culture (i.e., culture tied to a particular place).

\section{ETHICS OF THE SOUL}

The contemporary world is submerged in social and information networks, which makes it difficult to maintain a physical connection with a place. Thus, the spiritualization of urban places is a reaction to melancholy, the way for a body and a physical place to unite. A group of teens not having their own place has to gather somewhere. In Kolomyitseva's research, teenagers' social circles are found in gateways, at back doors, and in stairwells. Teens hang out there. They also feel nostalgic for transit places, which give them a feeling of safety, of being at home (a feeling of belonging is established between a person and a place). Below we can see one example: 
For some reason, my memories about that place [the dormitory stairwell] are full of love and tenderness. I spent nearly all my time there. I was 13 or 14 back then .... I remember skipping classes and not doing my homework-instead, I rushed to the stairwell after school. The teenage transition age: I wanted freedom that I could not find in a room of 12.5 square metres where 4 people had to manage to live together. It was unbearable for me to be constantly in the presence of my parents. The stairwell offered space, complete freedom, and no control at all. Mostly I hung out with my friend and two other guys. My first cigarette, first kiss when playing the "spin the bottle" game ... OMG, this is embarrassing. All those things happened on the stairs. We listened to IarmaK's lyrics and just enjoyed the atmosphere of total freedom. We did not care about the dirt or the garbage lying on the stairs. We ate sunflower seeds, made out with our boyfriends while sitting on their lap-and life was wonderful. At least this is how I saw it when I was 13 (A.A., 19 years old).

Such feelings do not always imply a neighbourhood; they can be built on common ground of taste and a need for intimacy. Adults come to public places that evoke such feelings in search for social belonging. These are the customers of the "Some Like It Hot" Gastrobar and the "Old Man Hemingway" $(\mathrm{OMH})$ bar, the "Bourbon" coffee place, and the "Oblomov" anticafé. Loyal oldtimers and new clients stop and meet each other here, and these meetings become a ritual. The $\mathrm{OMH}$ bar's motto is "You'll never drink alone" (a reference to Hemingway's short story “A Clean, Well-Lighted Place,” 1933). This is the exact opposite to the feeling one gets in clubs (restaurants, night clubs), where the importance of a person is determined by his or her sociability and readiness to make contacts. The feeling of belonging in a soulful place is the opposite of officialdom, formality, or publicity, where it is tough to find sincerity, intimacy, or love. Iuliia Kolesnikova describes such a place as follows:

A waiter doesn't necessarily have to smile when meeting a client; a barman doesn't need to put a straw in a not-yet-finished cocktail for one to taste it and check whether it's good enough; a cleaning lady can definitely skip the step of patting a student who is staying late on the shoulder to ask about his or her studies. But when the above-mentioned routine happens, a special warm, homely, and friendly atmosphere ensues.

There are several key features to evoking a feeling of belonging. One is intimacy. This category denotes, first, what is private to us (what we own, what we have the right to, what we belong to), second-what is of a secret nature (what we do not share with a stranger or what only we know), and third-what seems to be close to us, well-known, that we can relate to. The semantic field of intimacy binds these concepts with feelings (of love, friendship, sympathy), positive emotions, and sensations-first and foremost of safety, comfort, warmth, closeness, and seclusion. Intimacy 
refers to such places and objects like home, family meals, doors, and shutters, reliably protecting us from the outside world. Intimacy brings up images of holding hands, hugging, kissing, signing cards and secret notes, falling in love and breaking up. Intimacy can be found in places that belong to an individual, not to the public. These places are available to those who are invited. "The stairwell is a space on the border between the personal and the public. Teenagers value the atmosphere created by darkness, music and alcohol. They are not burdened by etiquette norms, and they give way to their feelings. So, no one's offended by a couple kissing," as Kolomyitseva points out in her observation.

When the students recognized intimacy and belonging as the constituting elements of soulful places, guarded by a "genius loci,"' they also had to admit that those places were the source of feelings vital for human existence-safety, satisfaction, and care. Kolesnikova shares her impressions about the $\mathrm{OMH}$ bar:

People are always glad to see you at the OMH. They truly care about you, be it your cat or your latest fling. If you fall asleep by the end of the evening, overestimating your drinking potential, someone will put a pillow under your head and cover you carefully with a blanket, and at the end of the shift, somebody will call a taxi, ride home with you, and walk you to the door.

Another reason why people feel happier in a soulful place is that they can be themselves there, not hiding their weaknesses or flaws. The acceptance of each other's vulnerability, according to a Russian sociologist Aleksandr Bikbov, presumes some degree of imperfection and weakness (par. 2). This contributes to feelings of interest and importance, similar to how people are with friends. That is what a teenager who frequents the dorm stairwell told the student researchers:

The first time I tried alcohol and cigarettes here, I decided I did not need them. Then I was afraid of not being a part of the group anymore, but that never happened. I am glad people accepted me the way I was and no labels interfered. (N.S., 16 years old, lives in an apartment next to the dorms)

That is the moment of becoming a grown-up: here, at the stairwell, teenagers get this common feeling. "Soulful places" perform similar tasks and requests for every age-these are the places of an extreme social experience that allows people to go beyond formalized relations and brings a feeling, even if it is fleeting, of genuine human bonding. Such socialization is manifested in a community with standards that promote tolerance for weakness and acceptance of each other's differences.

${ }^{6} \mathrm{~A}$ "genius loci" was the protective spirit of a place in classical Roman religion. 


\section{AESTHETICS OF THE SOUL}

The home, which fulfills one of the simplest human needs, is the taproot of soulful places. These places, similar to the home, can be characterized by a dreaminess. In Poetika prostranstva (The Poetics of Space), Bachelard writes: "in addition to protective functions it provides, home inspires values of daydreaming that stay alive even when the home does not exist anymore" (135). Daydreaming is connected with the aesthetics of places. Aesthetics is determined not as much by physical parameters as by the power of imagination. Softness, dimmed light, and simplicity if not scarcity of the interior décor are typical of soulful places. Bright lights or vivid, shiny images may be harmful - they block the imagination. The simpler the place is, the brighter are the dreams of a home within it.

The aesthetic qualities of a place can also be seen in the views that it offers from its windows. Thus, soulfulness in the city can be found where the best sunsets are-e.g., the U1 building at the Kharkiv Polytechnic-and where the best panorama view is-the "Trudovi rezervy" (Labour Reserves") Stadium. Such special aesthetic parameters are characteristic of soulful places, and not only of "shelters" (hidden, little-known cafés below ground) or hard-to-reach places with good panoramic views, but of vivid urban "scenes," too. In a another student-led study of the Kharkiv National Academic Opera and Ballet Theatre, conducted under the supervision of Borys Filonenko in the fall of 2018, one finds how the unusual aesthetic qualities of a place lead to the birth of alternative cultural groups and to their creation of a special meeting place for themselves ("Pidsumok kursu").

According to the field report produced by Filonenko's students, the Kharkiv Opera's building is described as a terrible, gray, angular, and ominous building: "It feels oppressive, but I don't feel too negative about it, I just perceive it as it is"; "Outwardly ugly, but it has a lot of legends"; "Built with an eye to ideology"; "I admire the grandeur, the scale, and internal structures, but the theatre is perceived as something not quite alive." At the same time, the theatre is said to be "amazingly beautiful"; "it captures the spirit; the form is amazing, and the layout is complex"; and "[it is ] an extremely distinctive structure with a few non-functional appendices, and you could even say that the [Kharkiv Opera] is absolutely inappropriate in the context of the historical downtown" ("Pidsumok kursu"). It is possible that the brutality and ambiguity of this architectural object in fact created the necessary aesthetic conditions for it to become soulful. The ambivalence of the architectural object in the urban imagination attracts a young audience: skaters, musicians, dancers. These groups choose empty, unoccupied spaces - both literally and figuratively.

The majority of respondents believes that the Kharkiv Opera performs the function of a community hub, "but only for certain social groups and at 
certain times," as one of the respondents indicates: "for example, for skateboarders and others riders more often than for those who dance the salsa." "Yes, this is the place where many creative people gather; interesting events take place here, but mostly it is a place only for specific urban groups" (as quoted in Kolomyitseva's field diary). Hence, while an aura of "soulfulness" can be achieved in both the interior of a cozy café near the old city and the brutal exterior of an unsuitable meeting place (such as a stairwell), grotesque forms are more attractive-especially for young people, teenagers, or bohemians, but these places are usually not for everyone. Therefore, they are populated by those who do not have their own place in the city, at least. That is why in different cities a soulful place is often called "iama" ("the pit") (Petrova; Kut)

The dichotomy of the internal and external space ensures soulfulness. Its two poles are home (shelter) and the public sphere (scene). The home zone is focused on internal development, with a narrow circle of connections. The home zone provides a safe, intimate atmosphere, where even strangers can open up to each other-to share secrets and flaws. The home zone is not necessarily the same as the "home." It could be a cozy coffee shop, a gas station, a stairway, or a ravine behind a dorm. These spaces are different from the open space at the Kharkiv Opera, gastrobars, and "authentic" restaurants. The Kharkiv Opera gives the opportunity to interact with representatives of other subcultures. Exchange of ideas promotes reflexivity, allows one to better understand his or her city and the opportunities it offers. Here, the communication skills of people, their ability to empathize, as well as the smells and sounds are important.

But the private and public types of urban soulfulness share one feature-these are empty places that a particular group of people can fill with certain content, hobby, or feeling: love of coffee, beer, parenthood, teenage games, student life, and so on. The visitors to soulful places are reminiscent of the neotribes described by Michel Maffesoli, where the relationship is temporary but intimate enough to ensure informal social interactions.

Hence, according to the students' fieldwork, we can point to features of soulful places that architects can use as guidelines-a soulful aura cannot simply be transferred from one place to another. A soulful aura is difficult to fake or simulate. Any changes in the structure of the community's aesthetic or moral ethos can lead to negative consequences. Unnecessary improvement or revitalization programs can also destroy established networks of trust and social connection. 


\section{CONCLUSION}

Referring to Zukin's concept of the "authentic place," my students studied several urban places in Kharkiv, unique due to the presence of a special atmosphere-soul. Their fieldwork led to a better understanding of the context of soulfulness. The main characteristics of a soulful place are participation, personal connections, sincerity, and family ethos. These traits give us reason to call such places a kind of "home in the city." An open question remains: why is there demand for soulfulness in Kharkiv? Is it a response to the general situation of anxiety in a front-line city? This essay sees the rise of soulfulness in Kharkiv as the result of two interconnected processes.

On the one hand, it represents general progress toward a new urban sensitivity. This trend to soulfulness looks like a rethinking of sentimentalism. Modern individuals have lost their intimate contact with things and places, according to Bachelard; they are devoured by the external world. The old world is hidden in local history museums and the calmness of small towns, while speed and chaos dominate the urban metropolitan life. The characteristics of a soulful place are opposite to the hustle of urban centres. That is why a house nearby in a soulful place might sell better, due to the soulful place's aura of sincerety. Hence, the soul can be a tool that economic elites use to boost housing prices in areas where Kharkiv's soulful places are concentrated. However, let us recall Zukin, who spoke of the need to understand that the rapidly growing demand for soulfulness can also lead to a crisis of authenticity, chasing away the very people who give these places their soulful aura.

On the other hand, Kharkiv's soulful places are a form of protection against the high level of politicization of the public sphere in Ukraine. General anxiety, irritation, and political fatigue are the factors behind a broad range of soulful authentic cafés and bars. Coffee shops where conversations about politics are forbidden, bars where you will be greeted like an old friend, and spontaneous meeting places that arise in the most uncomfortable or unexpected conditions (metro, stairwell, gas stations) are just a few examples of collective behaviour aimed at restoring order-even while being disturbed by news from the war front. Their common feature is that they are a reaction to the ongoing war in the neighbouring Donbas region, which is difficult to cope with using the standard culturally accessible means. Regardless, this conflict delegitimizes the existing order and reveals cracks in the community that Kharkiv residents are trying to repair in such soulful places. 


\section{Works Cited}

Abdrekhimova, Aleksandra. "Piterskii Dj Bary kak ob"ekt sotsiologicheskogo analiza." Zhurnal sotsiologii i sotsial'noi antropologii, vol. 10, no. 1, 2007, pp. 11421.

Apostolova-Sossa, Liubov, and Alirza Mamedov. "Humanizatsiia publichnoho prostoru istorychnykh mists', chy iak zberehty dukh mistsia." (Ne)zadovolennia publichnymy prostoramy. Urbanistychni studii, vol. 3, 2017, pp. 243-55.

Bachelard, Gaston. Poetika prostranstva. Ad Marginem Press, 2014.

Bikbov, Aleksandr. "V poiskakh prostranstva sovmestnogo udovol'stviia." Zapovednik, 20 June 2017. https://zapovednik.space/material/v-poiskahprostranstva-sovmestnogo-udovolstvia. Accessed 3 Sept. 2018.

Kut, Andry. "The 'Pit' in Moscow Was Fenced because of 'Active Use' Space." Hand of Moscow, 28 June 2019, https://handofmoscow.com/2019/06/28/the-pit-inmoscow-was-fenced-because-of-the-active-use-space/. Accessed 14 Nov. 2019.

Petrova, Ol'ga. "Khar'kovskie muzykanty deliatsia muzykoi s temi, kto ee liubit." Krugom Khar'kov, 30 Aug. 2016, http://citysite.kh.ua/newsculture/2016/08/30/xarkovskie-muzyikantyi-delyatsya-muzyikoj-s-temi-ktoee-lyubit/. Accessed 14 Nov. 2019.

Maffesoli, Michel. The Time of the Tribes: The Decline of Individualism in Mass Society. SAGE, 1996.

Norberg-Schulz, Christian. "Phenomenon of Place." Architectural Association Quarterly, vol. 4, 1976, pp. 3-10.

“Pidsumok kursu 'Humanitarni doslidzhennia mista,' pidhotovanyi studentamy kursu." Kafedra arkhitektury ta urbanizmu, Kharkivs'ka Shkola Arkhitektury, 2018.

Zukin, Sharon. The Naked City: The Death and Life of Authentic Urban Places. Oxford UP, 2010. 
Appendix 1. "State of Soul." Exhibition Plan

The exhibition structure was based on the two binding home principles according to Bachelard: house as a vertical structure (it rises) and house as a concentrated being (it appeals to our feeling of centrality). If a soulful place was a house in a city, we walked through it-from the basement to the roof. The students' projects were arranged according to their positions in the "house."

\begin{tabular}{|c|c|c|c|c|c|}
\hline & $\begin{array}{l}\text { Student's } \\
\text { name }\end{array}$ & Case & $\begin{array}{l}\text { Building } \\
\text { image }\end{array}$ & $\begin{array}{l}\text { Location } \\
\text { inside the } \\
\text { School of } \\
\text { Architecture } \\
\text { building }\end{array}$ & $\begin{array}{l}\text { Exposition } \\
\text { solution }\end{array}$ \\
\hline 1 & $\begin{array}{l}\text { Dmytro } \\
\text { Legeida }\end{array}$ & $\begin{array}{l}\text { "E," } \\
\text { basement } \\
\text { bookstore }\end{array}$ & Basement & Basement & $\begin{array}{l}\text { The tunnels' } \\
\text { system with } \\
\text { books and } \\
\text { sketches. Going } \\
\text { down to the } \\
\text { basement means } \\
\text { dreaming, } \\
\text { searching for } \\
\text { mythical } \\
\text { treasures in } \\
\text { books. }\end{array}$ \\
\hline 2 & $\begin{array}{l}\text { Iuliia } \\
\text { Kolesnikova }\end{array}$ & $\begin{array}{l}\text { "Starik } \\
\text { Khem" bar }\end{array}$ & Garage & $\begin{array}{l}\text { Room } \\
\text { between the } \\
\text { basement } \\
\text { and the main } \\
\text { floor }\end{array}$ & $\begin{array}{l}\text { The corner in the } \\
\text { house that } \\
\text { ensures stability. } \\
\text { Brochure with a } \\
\text { description and } \\
\text { illustrations. }\end{array}$ \\
\hline 3 & $\begin{array}{l}\text { "Some Like It } \\
\text { Hot" team }\end{array}$ & $\begin{array}{l}\text { "Some Like } \\
\text { It Hot" } \\
\text { gastrobar }\end{array}$ & $\begin{array}{l}\text { Large } \\
\text { living } \\
\text { room }\end{array}$ & $\begin{array}{l}\text { Room on the } \\
\text { main floor }\end{array}$ & $\begin{array}{l}\text { Dining table, } \\
\text { comics }\end{array}$ \\
\hline
\end{tabular}


Table continues.

\begin{tabular}{|c|c|c|c|c|c|}
\hline & $\begin{array}{l}\text { Student's } \\
\text { name }\end{array}$ & Case & $\begin{array}{l}\text { Building } \\
\text { image }\end{array}$ & $\begin{array}{l}\text { Location } \\
\text { inside the } \\
\text { School of } \\
\text { Architecture } \\
\text { building }\end{array}$ & $\begin{array}{l}\text { Exposition } \\
\text { solution }\end{array}$ \\
\hline 4 & $\begin{array}{l}\text { "Bourbon" } \\
\text { team }\end{array}$ & $\begin{array}{l}\text { "Bourbon" } \\
\text { coffee place }\end{array}$ & $\begin{array}{l}\text { Kitchen } \\
\text { cupboards } \\
\text { with } \\
\text { coffee, tea, } \\
\text { sweets }\end{array}$ & $\begin{array}{l}\text { Cupboards in } \\
\text { the living } \\
\text { room }\end{array}$ & $\begin{array}{l}\text { Cupboard with } \\
\text { coffee; sketches } \\
\text { with a text } \\
\text { hanging on the } \\
\text { cupboard door. A } \\
\text { secret space, } \\
\text { which is not open } \\
\text { to everyone. }\end{array}$ \\
\hline 5 & $\begin{array}{l}\text { Kolesnyk and } \\
\text { Frants }\end{array}$ & $\begin{array}{l}\text { Salamander } \\
\text { building, } \\
\text { backyard }\end{array}$ & $\begin{array}{l}\text { Space next } \\
\text { to the } \\
\text { window } \\
\text { (with a } \\
\text { view from } \\
\text { the } \\
\text { window) }\end{array}$ & $\begin{array}{l}\text { Space next to } \\
\text { the window } \\
\text { in the living } \\
\text { room }\end{array}$ & $\begin{array}{l}\text { Sketches of the } \\
\text { window or of the } \\
\text { platbands, an } \\
\text { ashtray, a pillow } \\
\text { on the } \\
\text { windowsill. }\end{array}$ \\
\hline 6 & $\begin{array}{l}\text { Kateryna } \\
\text { Cherednyk }\end{array}$ & $\begin{array}{l}\text { The slope } \\
\text { behind the } \\
\text { dorms of } \\
\text { the Kharkiv } \\
\text { Aviation } \\
\text { Institute } \\
\text { (KhAI) }\end{array}$ & House roof & Balcony & $\begin{array}{l}\text { Photos or } \\
\text { sketches with a } \\
\text { view of the slope }\end{array}$ \\
\hline 7 & $\begin{array}{l}\text { Mariia } \\
\text { Kolomyitseva }\end{array}$ & $\begin{array}{l}\text { Stairway in } \\
\text { the } \\
\text { dormitory }\end{array}$ & $\begin{array}{l}\text { Stairs to } \\
\text { the attic }\end{array}$ & $\begin{array}{l}\text { Stairwell to } \\
\text { the second } \\
\text { floor }\end{array}$ & $\begin{array}{l}\text { Sketches on the } \\
\text { walls, } \\
\text { inscriptions, } \\
\text { graphics, floor } \\
\text { plan, garbage }\end{array}$ \\
\hline
\end{tabular}


Table continues.

\begin{tabular}{|l|l|l|l|l|l|}
\hline $\begin{array}{l}\text { Student's } \\
\text { name }\end{array}$ & Case & $\begin{array}{l}\text { Building } \\
\text { image }\end{array}$ & $\begin{array}{l}\text { Location } \\
\text { inside the } \\
\text { School of } \\
\text { Architecture } \\
\text { building }\end{array}$ & $\begin{array}{l}\text { Exposition } \\
\text { solution }\end{array}$ \\
\hline 8 & $\begin{array}{l}\text { Kateryna } \\
\text { Troshyna }\end{array}$ & $\begin{array}{l}\text { "Oblomov" } \\
\text { anticafé" }\end{array}$ & $\begin{array}{l}\text { Attic, } \\
\text { children, } \\
\text { playground }\end{array}$ & $\begin{array}{l}\text { Children's } \\
\text { architectural } \\
\text { studio }\end{array}$ & $\begin{array}{l}\text { Board games, } \\
\text { sketches, texts, } \\
\text { vintage items }\end{array}$ \\
\hline 9 & $\begin{array}{l}\text { "The gas } \\
\text { station" team }\end{array}$ & $\begin{array}{l}\text { Gas station, } \\
\text { coffee spot }\end{array}$ & $\begin{array}{l}\text { Spot on the } \\
\text { way from } \\
\text { home to } \\
\text { work }\end{array}$ & $\begin{array}{l}\text { Span on the } \\
\text { grand } \\
\text { stairwell }\end{array}$ & $\begin{array}{l}\text { Coffee to go, } \\
\text { sketches, texts }\end{array}$ \\
\hline
\end{tabular}

An exposition of the "Some Like It Hot" case in a format of comics and board game is presented below.

Figure 1.

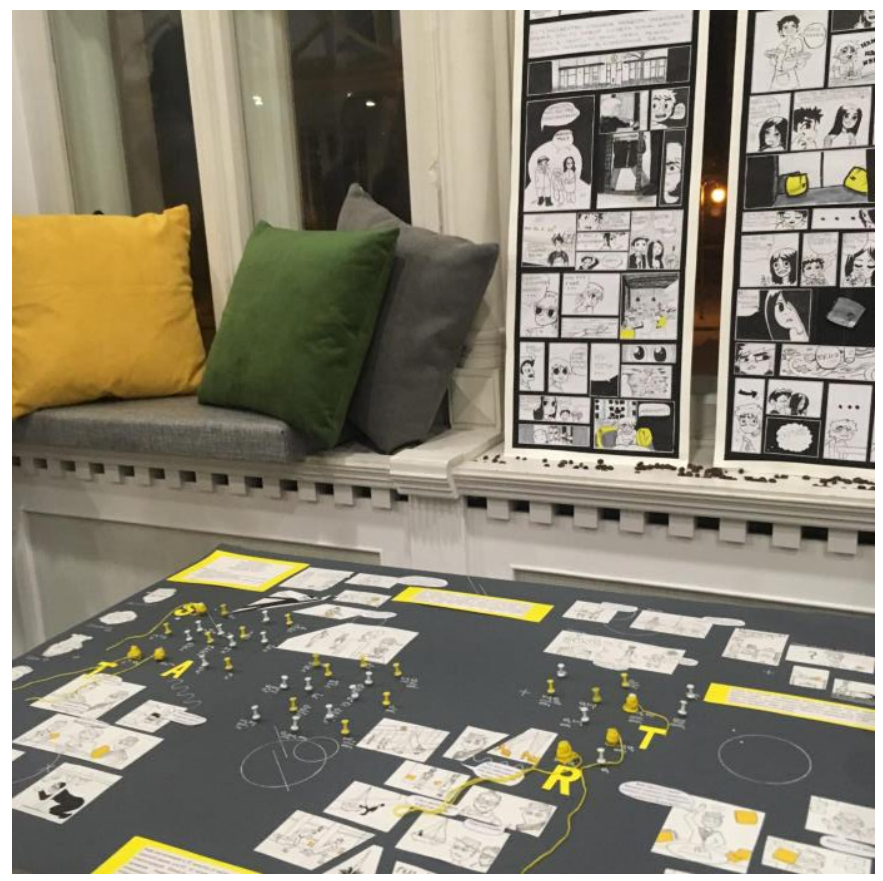


Figure 2.

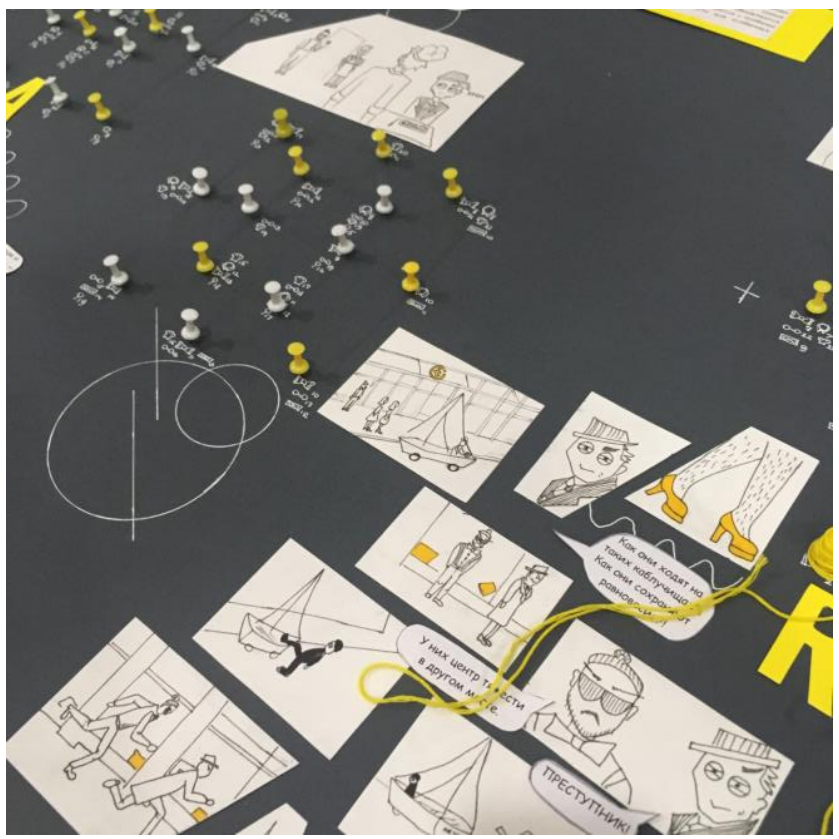

Figure 3.

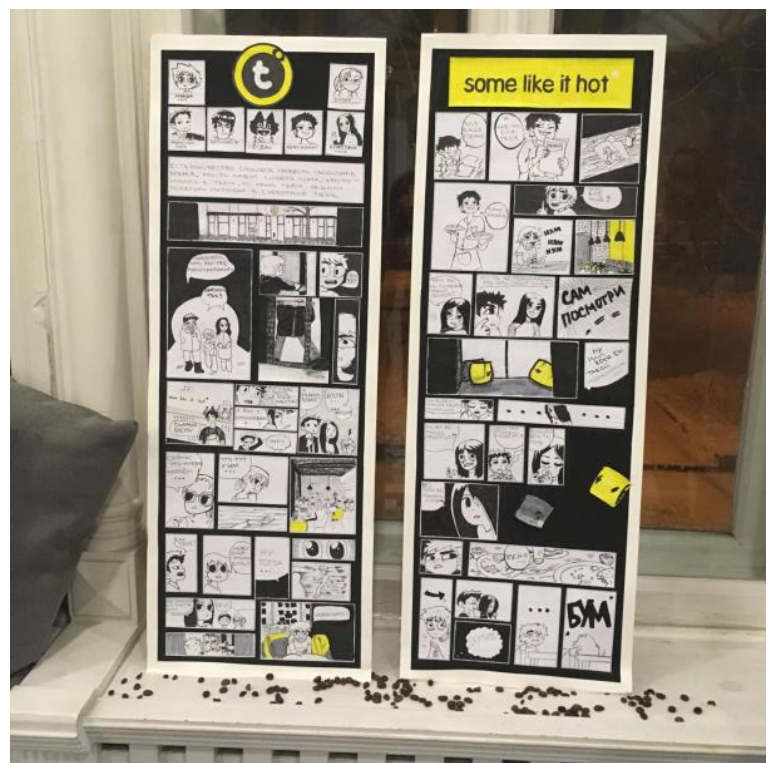

(c) 2020 East/West: Journal of Ukrainian Studies (ewjus.com) ISSN 2292-7956 Volume VII, No. 1 (2020) 
Figure 4.

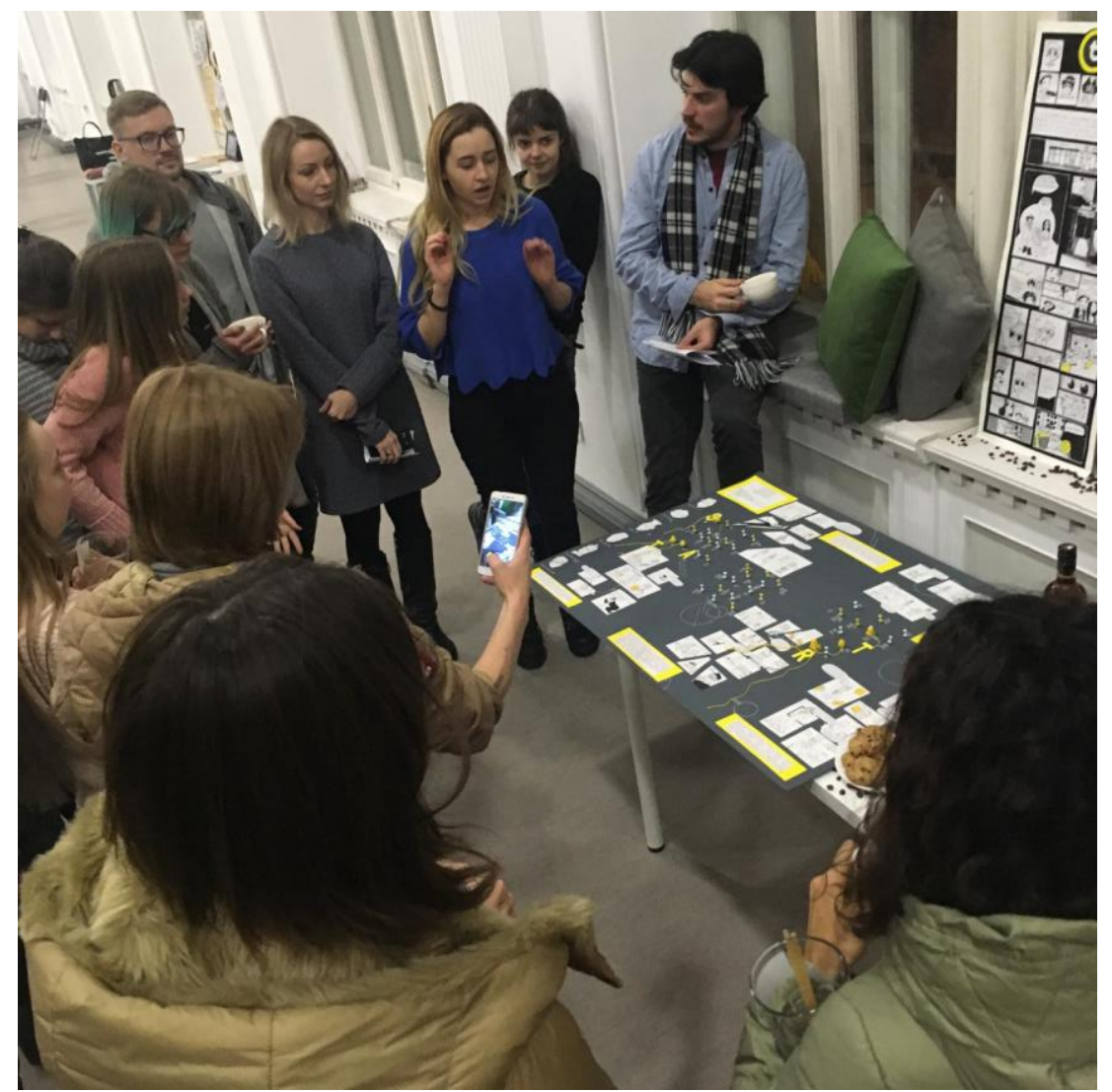


Figure 5.

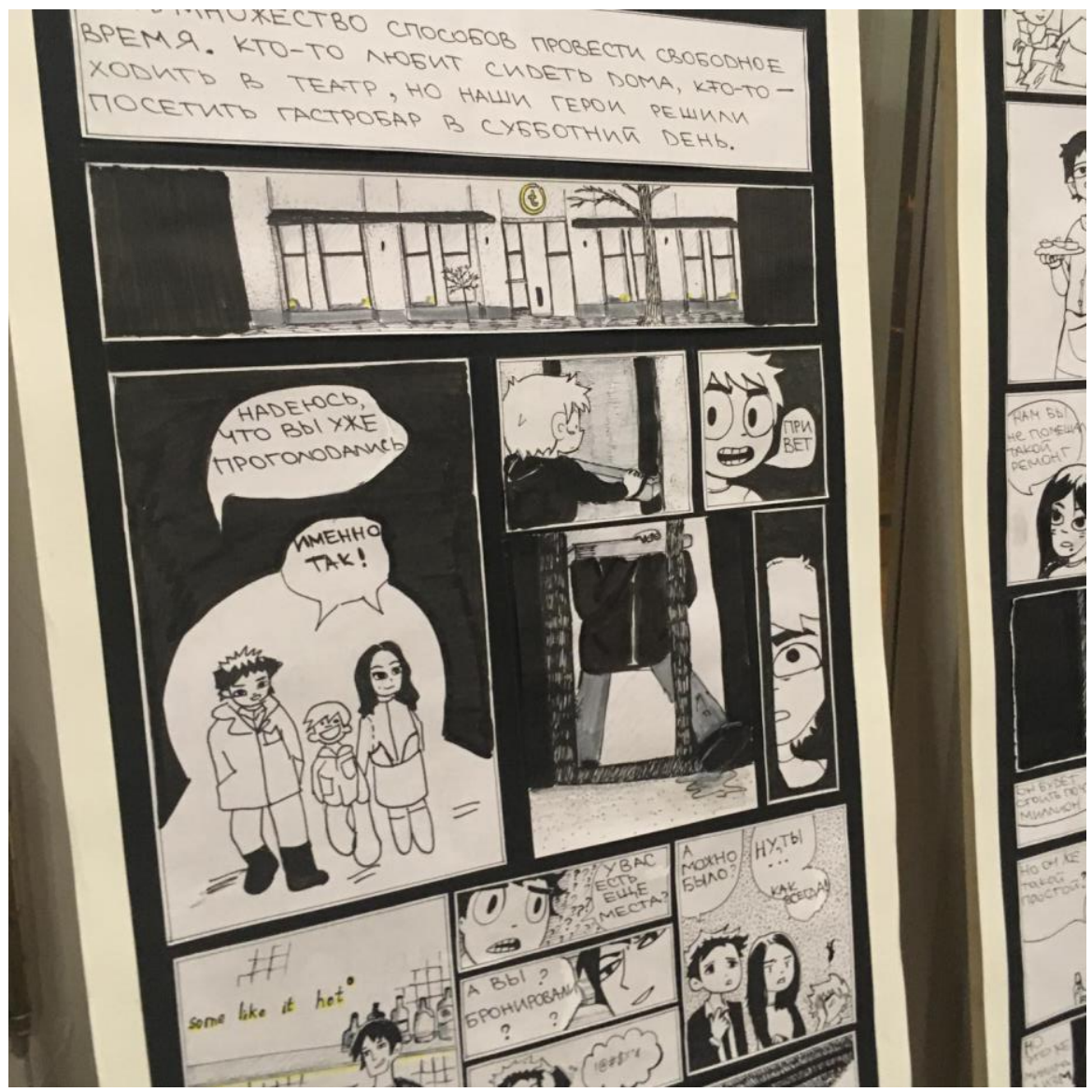




\section{Appendix 2. Research Cases}

1. "Some Like It Hot" gastrobar. Address: 71 Sums'ka Str., Kharkiv. Team: Iana Izmailova, Polina Sanzharevs'ka, Hanna Pylypenko, Kateryna Pylypenko, Alisa Aleksandrova, Diana Nasiedkina, Ruslana Muratova, Iryna Kotliarova.

The name "Some Like It Hot" is very suitable for a café-bar. It was opened in 2015, and the core idea of the place was inspired by Chicago in the 1930s, when a Dry Law prohibited the production, sale, and consumption of alcoholic beverages. Such "underground activity" is the subject of this place. Informal relations of clients and the staff are also a part of a special atmosphere of this place. On the American Thanksgiving Day, "Some Like It Hot" serves turkey to each of the visitors, as if they were members of a big family. A friendly atmosphere brings up a positive emotional response in customers.

2. "Bourbon" coffee place. Address: 22 Kul'tury Str., Kharkiv. Team: Nataliia Kozub, Tetiana Telnova.

The "Bourbon" coffee place is located in a $5 \times 6$ square metre space. Every visitor is welcomed, and regulars are even more warmly welcomed. One will not find fake joyfulness, excessive reverence, or disrespect here. What customers will see is a sincere interest in them and their lives. These values can be noticed by watching the staff communicate; they were also mentioned by Mykola, the owner and barista, in the interview: he emphasized heartfulness, honesty, trust, and friendship as the core values that he wanted the space to project (interview dated 12 Jan. 2018). The norms of behaviour arise from respect for one another. There is also a semi-serious coffee cult in "Bourbon," an important part of its atmosphere. For instance, Mykola takes it as a personal insult if people add sugar to coffee. The staff is well-educated with respect to the coffee business and has much enthusiasm for it. Mykola is the owner and the soul of the coffee place. He attracts numerous clients to the place with his communicativeness, charm, and openness. Talks in "Bourbon" are versatile, honest, witty, bright, and fascinating. Everyone has a chance to share something about himor herself.

3. " $\boldsymbol{G}$ " Bookstore. Address: 3 Sums'ka Str., Kharkiv, basement of the building. Designed by Dmytro Legeida.

The " $\epsilon$ " bookstore has a transition zone that allows guests to adjust to a different rhythm, not only when entering but also when leaving the place. There is a light aftertaste after visiting the store, when one understands that his or her visit has come to an end, but they have not yet fallen into a noisy and rush world outside its premises. Customers still have a couple of minutes to enjoy their purchase and to think over the things they perused in the store. While going up the stairs one can stop and take a look at the books on the shelves along the stairs. The secret of the soulfulness in this store is in the labyrinth structure that divides it into separate compartments, or worlds. 
4. “Oblomov” anticafé. Address: 10 Marshala Bazhanova Str., Kharkiv. Designed by Kateryna Troshyna.

The Oblomov anticafé is a place where people can get together late in the afternoon, to celebrate something (often a birthday), or just spend time together, play board games they might not have at home, laugh, and relax. The Oblomov offers a healthy distraction (e.g., from gadgets), and there are no bored people here, staring at their smartphones. Sometimes it is challenging to start a new conversation in a café, but at the Oblomov people feel at ease talking to their friends or other customers, and this is what is important.

5. Slope behind the dorms of the Kharkiv Aviation Institute (KhAI). Address: 6B Elektroinstumental'nyi Provulok, Kharkiv. Designed by Kateryna Cherednyk.

This slope is a favourite for all the KhAI students: from college freshmen moving into a dormitory to alumni remembering their student years. The slope behind the KhAI dorms is equally loved by those on the verge of being expelled and those on prestigious scholarships, by couples in love and by students employed in huge, bustling places. Also, the slope is sometimes used for the most sacred KhAI tradition-riding in a washbasin bucket. This used to be done in the long dorm corridors, but one year it was decided to use the slope as a more suitable place. Most people like spending time outside, and KhAI students have their own piece of nature right next door.

6. Cour d'honneur at the Salamander House. Address: 17 Sums'ka Str., Kharkiv. Team: Ievhen Frants and Oleh Kolesnyk.

Salamander House is rather small, about 18 x 30 square metres in area. It has a "cour $d$ 'honneur," the main courtyard in front of the building, flanked by the main building and two side wings.This inner courtyard surrounds the building on three sides, and the fourth side faces Sums'ka Street. There is a row of cafés and shops on the ground floor of the building; entrances and windows of the public places all look toward the inner court. There is also a post-office kiosk and a bus stop on the side of the court that faces the street. The "cour d'honneur" structure of the building brings feelings of coziness and safety.

Salamander House has its own history. Even passersby will notice signs and symbols that belong to a particular epoch. A few generations have lived and worked here; shops, cafés, and offices have been opened and closed, but the original "cour $d^{\prime}$ 'honneur" structure is preserved. While being in this place, people realize that they are in a city that is more than three and a half centuries old. At the same time, customers do not feel insignificant here. The rhythm of a classical architecture is interrupted by the greenery of trees that have miraculously survived the turbulent epochs. 
7. “Starik Khem" (Old Man Hemingway, OMH) Bar. Address: 8 Svobody Square, Kharkiv. Designed by Iuliia Kolesnikova.

A bar is always a social place, but in some bars one might sit with his or her back straight and legs crossed, and in others, in a more relaxed posture, hugging the knees, for example. The latter case is the $\mathrm{OMH}$ bar. The absence of formality in the staff and the atmosphere spreads to the visitors. Another secret of its soulfulness is tactility. The OMH bar occupies two medium-sized rooms of 60-70 square metres and one of the rooms has a huge bar. When the place is full, people have to swerve in the aisles, but even then they will not escape tactile contact: they touch someone, someone touches them. Almost everyone who comes to this bar once, comes a second time because of the basic instincts: everyone seeks warmness, love, support, and a genuine interest in them. The atmosphere of home and belonging to a big family is a secret ingredient that make people come back to "Starik Khem."

8. The stairwell in family dorm building No. 5. Address: 19 Derev''ianko Str, Kharkiv. Designed by Mariia Kolomyitseva.

The stairwell in family dorm building No. 5 is actively used by different people, but the main space users are teenagers (13-17 years old). They gather in small groups between the 4th and 8th floors, and between the 10th and 15th floors. This stairwell attracts teenagers from all the apartments nearby. The reason is the relative privacy of the stairwell; it is small and it is not a transit place. Teens are separated from adults by the three barriers: a room, a corridor, and a hall. Visitors to the stairwell listen to music, talk, laugh loudly, and might use filthy language on occasion. Girls and boys are in the same position, which can be noticed from the way they behave and treat each other: a girl and a boy can have a fight, they eat and drink the same, and no expressions such as "ladies first," "stop swearing in front of women," "give place to a lady," "be a gentleman and pay for the lady," "protect the lady" are heard here. Men and women are equal.

9. Gas station. Address: 7 Osvitians'ka Str., Kharkiv. Team: Viktor Rakov, Oleksandra Liapina, Hanna Sokolova, Vladyslava Bondareva, Ol'ha Mozhova.

Parents bring their children to school every day. They cannot skip this task or postpone it. Having accomplished it, a parent might feel relief or freedom. Many adults experience such emotions daily along a road section of 400 metres, between the school gates and the exit to the highway. The feeling of freedom is concentrated at the gas station situated on this road between the school gates and the highway. The coffee shop at this gas station is a source of joy at this time in the morning. The gas station's visit for these parents in not about gas anymore, it is about a comfortable place to stop for rest after bringing their child to school. 
Appendix 3. Soulful Places in Kharkiv. Map

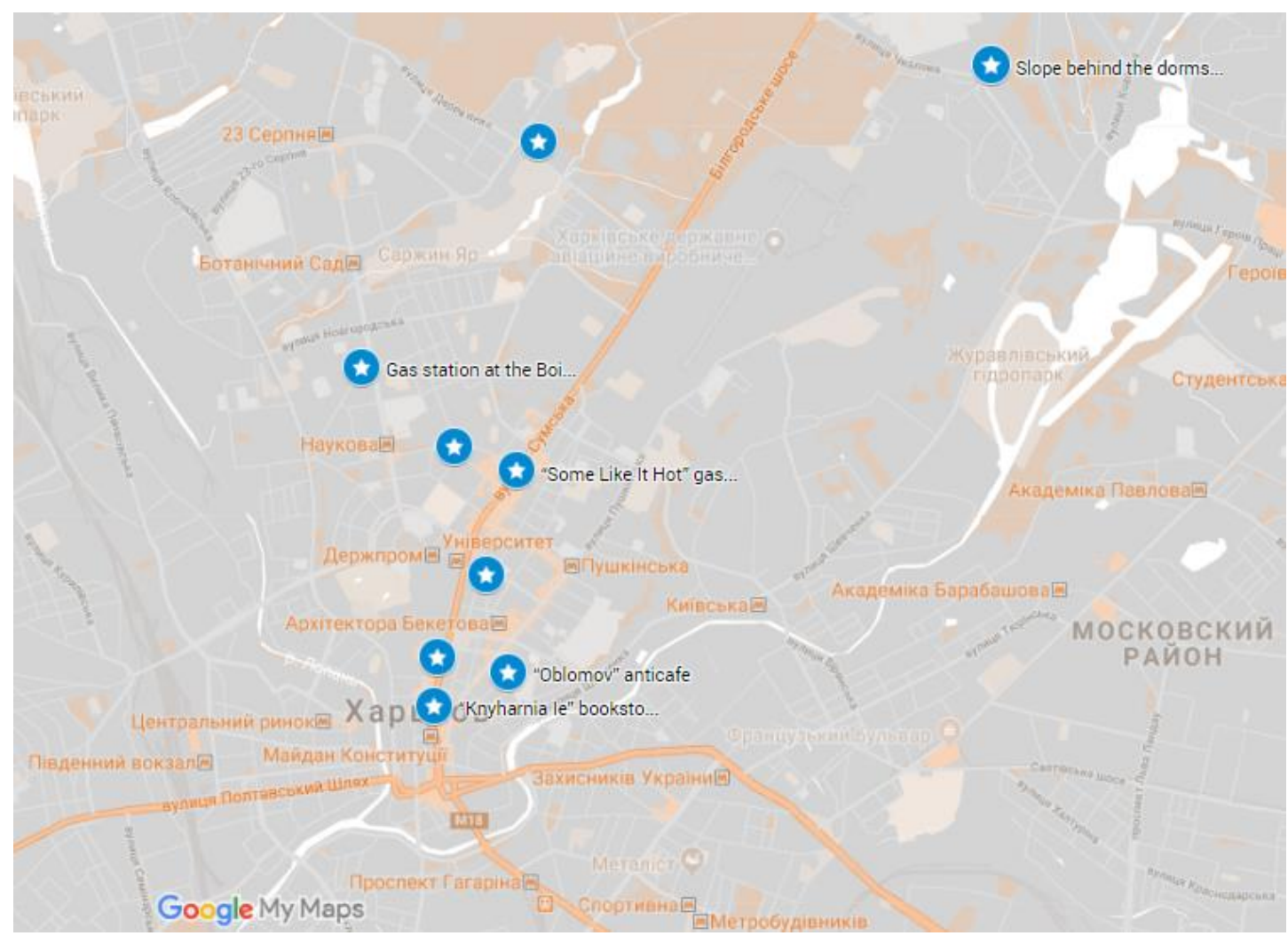

